\title{
Identifying Carbon Footprint Emitted by Geodetic Engineers in San Ildefonso Bulacan When Conducting Survey Activities
}

\author{
Florencondia, Noel T. ${ }^{1}$, Manzon, Donald Rick ${ }^{2}$, Wagan, Robert Anthony C. ${ }^{3}$, Mendoza, Darius R.. , Guerrero, \\ Ralph Lery U. ${ }^{5}$ \\ ${ }^{1,2}$ Graduate School, Nueva Ecija University of Science and Technology \\ ${ }^{3,4}$ Institute of Engineering and Applied Technology, Bulacan Agricultural State College \\ ${ }^{5}$ PLDT, Cabanatuan City
}

\begin{abstract}
Because of increasing concern about climate change and carbon emissions as a primary contributor, many companies and organizations are pursuing "carbon footprint" projects to estimate their contributions to global climate change. Calculating the carbon footprint is fundamental to understand how a company or organization's activities impact global sustainability. The main challenge is how to calculate it when environmental aspects are intangible assets. This study aims to identify the frequency of carbon footprint emitted by geodetic engineers from San Ildefonso, Bulacan when they are conducting site surveying activities. Thus, this study provides a comprehensive review if GE's from San Ildefonso, Bulacan are high contributors of emitted carbon using statistical data, a review of ground improvement methods that have been studied to reduce the carbon footprint, and the direction in which geodetic engineering should proceed in the future.
\end{abstract}

INDEX TERMS: Carbon Footprint, Carbon Emission, Geodetic Engineering

\section{INTRODUCTION}

"A carbon footprint is the total greenhouse gas (GHG) emissions caused directly and indirectly by an individual, organization, event or product." It is calculated by summing the emissions resulting from every stage of a product or service's lifetime.

Climate change plays a vital role in global issues attracted the eyes of researchers for solving issues such as global warming, ecological imbalance, technological issues and economic issues. Over the past few years many researches focused on identifying carbon footprints emission by different companies and organizations around the globe. Through this, they strategize on minimizing their emitted greenhouse gases to help solve the problem in climate change. The purpose of this research is to

\section{Sources of emissions}

- Personal transportation

- Energy consumption

- Water consumption

- Food

\section{OBJECTIVES OF THE STUDY}

\section{A. General Objectives}

This study is aimed to identify the carbon footprint emitted by geodetic engineers in San Ildefonso, Bulacan when they are conducting surveying activities.

\section{B. Specific Objectives}

Specifically, the study aimed to:

1. Identify or estimate the emitted carbon footprint of Geodetic Engineers in San Ildefonso, Bulacan when they are conducting surveying activities.

2. to formulate and strategize techniques to reduce their emitted carbon footprints, and

3. to make a direction in which geodetic engineering should proceed in the future to help eliminating or lessen their emitted carbon footprints.

\section{RESEARCH METHODOLOGY}

The researchers used a quantitative design to acquire information regarding the carbon emission of geodetic engineers in San Ildefonso, Bulacan while conducting surveying activities. In general, quantitative design is based with scientific method. Thus, the researchers used deductive reasoning, where the researcher formed the objective of the study, collected data to solve the problem, and then used the data for analysis. Afterwards, conclusions were made by the researchers to complete the study.

The data were collected electronically, by sending google forms to the respondents which contains the instructions for the survey as well as the needed information for the researchers. The respondents had their own usernames and passwords, known only by them, to access the form. The researchers used this to ensure the confidentiality of the 
survey collection process. In addition, it was already stated to the respondents that their individual responses would remain confidential and purely for research purposes only.

\section{RESULTS AND DISCUSSIONS}

This contained the data gathered during data collection process.

\section{A. Personal Transportation}

Figure 1., showing that the majority of GE's in San Ildefonso, Bulacan are using gas type engine when they are engaging in surveying activities. The data gathered were based on the answers of the responders and $100 \%$ of the GE's practicing in San Ildefonso, Bulacan participated. Base on the data presented they are generating a total of 20.62 tons of $\mathrm{CO}^{2} \mathrm{e}$ yearly.

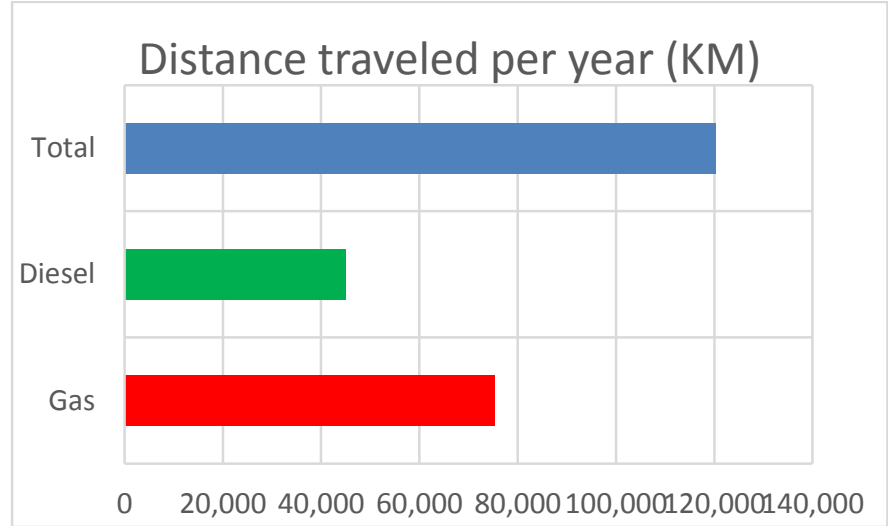

Figure 1

\section{B. Energy Consumption}

Figure 2., showing their individual energy consumption per year based on the gadgets and equipment's they are using including lightning, air-conditioning unit and etc. With respect to energy consumption they are generating 4.37 tons of $\mathrm{CO}^{2} \mathrm{e}$.

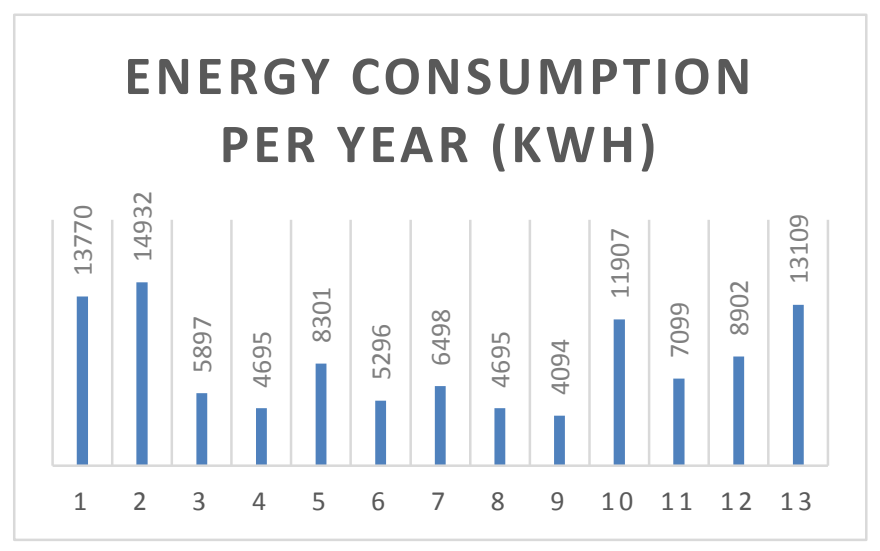

Figure 2

\section{Water Consumption}

Figure 3., showing their water consumption in a year from drinking water, flushing their toilets, car wash and other related activities involving water. According on this statistic their total generation of carbon emission for consuming water is 18.18 tons of $\mathrm{CO}^{2}$ e every year.

\section{WATER CONSUMPTION PER YEAR $\left(M^{3}\right)$}

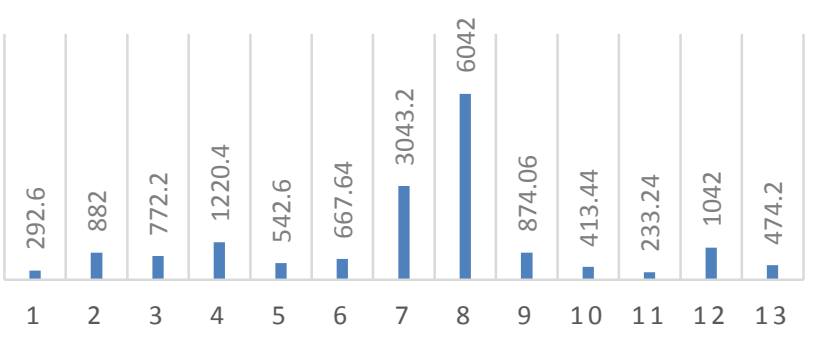

Figure 3

\section{Food Waste}

Figure 4., represents the food waste generated by everyone per year in kilograms. They are producing an average of 10.62 tons of $\mathrm{CO}^{2} \mathrm{e}$ yearly.

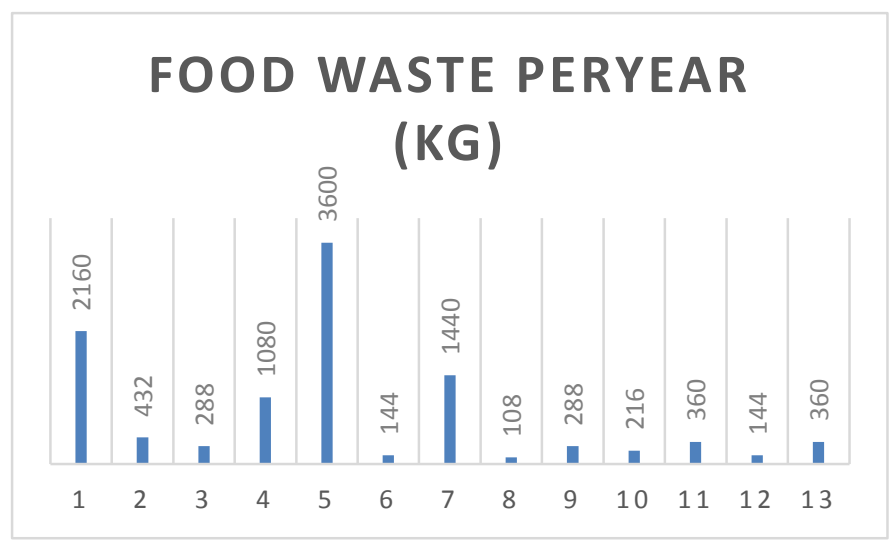

Figure 4

Carbon dioxide $\left(\mathrm{CO}^{2}\right)$ emissions per capita in the Philippines are equivalent to 1.22 tons per person (based on a population of $103,663,816$ in 2016), an increase by 0.12 over the figure of $1.11 \mathrm{CO} 2$ tons per person registered in 2015; this represents a change of $10.7 \%$ in $\mathrm{CO} 2$ emissions per capita.

Based on the gathered data the geodetic engineers in San Ildefonso, Bulacan has contributed 53.79 tons only of $\mathrm{CO}^{2}$ every year when they are practicing their profession. They are only contributing $5.19 \times 10^{-7} \%$ of the country's total carbon emissions which is a small portion and we can say that they are not a major contributor of greenhouse gases in the Philippines.

\section{CONCLUSIONS}

Greenhouse gases / carbon emission can be minimized by reducing the number of our travel, reducing electricity and water consumption and by composting our waste generated from foods. 
Carbon emitted thru surveying activities including office works by GE's in San Ildefonso, Bulacan has only small contribution on the nations carbon emission.

We can prevent the effect of global warming in being responsible and by restoring our ecology thru planting trees and by conserving our natural resources. By also using energy efficient devices we can help in reducing our generation of carbon dioxide.

This study provides a statistical review of the $\mathrm{CO} 2$ emissions from GE's of San Ildefonso, Bulacan. Global warming, accelerated by increases in $\mathrm{CO} 2$ emissions, creates abnormal climate events around the world that change the properties of soil over the short and long term, resulting in Hazards such as abnormal weather conditions, landslides, ground subsidence, levee failures, soil degradation, and coastal erosion.

\section{REFERENCES}

1. Gao, T., Liu, Q. \& Wang, J. (2013), Institute of Project Management, School of Mechanics and Civil Engineering, China University of Mining and Technology, Xuzhou, China: A comparative study of carbon footprint and assessment standards.

2. Durojaye, O., Laseinde, T. \& Oluwafemi E. (2019): A descriptive review of carbon footprint.

3. S.R. Raj Kumar, S. Shiju Gladwin, P.J. Winston Reno, K. Vignesh, G. Ajith, I. P. Rakhesh (2020): Carbon Footprint Analysis for an Engineering College for Sustainable Development in The Institution.

4. E. Sutherland, Research Associate, LINK Center (2009), Climate Change: the Contribution of Telecommunications.

5. Chen, S., Liu, Z., Chen, B., Zhu, F., Fath, B., Liang, S., Su, M., \& Yang, J., (2019): Dynamic Carbon Emission Linkages Across Boundaries.

6. Chang, I., Lee, M., \& Cho, G. (2019): Global CO2 Emission-Related Geotechnical Engineering Hazards and the Mission for Sustainable Geotechnical Engineering.

7. Abeydeera, L., Mesthrige, J. W., \& Samarasinghalage, T. I. (2019): Global Research on Carbon Emissions: A Scientific Review.

8. Lopez, E. L., Barral, M. \& Morla, J. C. (2020): Methodology for Carbo Footprint Calculation Towards Sustainable Innovation in Intangible Assets.

9. H. Scott Matthews, C. T. Hendrickson \& C. L. Weber, Carnegie Mellon University (2008): The Importance of Carbon Footprint Estimation Boundaries.

10. A. Fehske \& G. Fettweis, Technische Universitat Dresden (2014): The Global Footprint of Mobil
Communications: The Ecological Economic Perspective.

11. Center for Sustainable Systems, University of Michigan. 2020. “Carbon Footprint Factsheet.” Pub. No. CSS09-05. 